\title{
Conservation Status of the Chilean Woodstar Eulidia yarrellii
}

\author{
CRISTIÁN F. ESTADES, JUAN AGUIRRE, MARTÍN A. H. ESCOBAR, \\ JORGE A. TOMASEVIC, MARÍA ANGÉLICA VUKASOVIC and CHARIF TALA
}

\section{Summary}

We assessed the conservation status of the Chilean Woodstar Eulidia yarrellii, a small hummingbird endemic to a few desert valleys of northern Chile and southern Peru. Although no population studies had been conducted, this rare species was presumed to have undergone a severe population decline during the past decades. Fieldwork in Chile produced a population estimate for September 2003 of 1,539 individuals $(929-2,287 ; 90 \% \mathrm{CI})$, located in just two valleys: Azapa and Vitor. There was no evidence of stable populations elsewhere. Our observations tend to confirm the hypothesis of a past decline and evidence points to three main factors driving that trend: ( 1 ) Most natural habitat has disappeared and the species relies mostly on artificial resources for feeding and nesting. (2) The start of heavy use of pesticides in the Azapa valley in the 196os in order to control the Mediterranean fruit fly and other crop pests coincides with the last reports describing the species as abundant. (3) The irruption in the last two decades of the Peruvian Sheartail Thaumastura cora has apparently exerted serious competition pressure on the species. These findings support the classification of the species as globally Endangered. We describe the main lines of action of the recently approved Recovery Plan for the Chilean Woodstar.

\section{Introduction}

The Chilean Woodstar Eulidia yarrellii is a small hummingbird endemic to desert valleys of northern Chile and southern Peru (del Hoyo et al. 1999). Stattersfield et al. (1998) include the species as one of the characteristic species of the Peru-Chile Pacific slope Endemic Bird Area. Although no formal population assessment has ever been conducted for this species, during the past two decades there have been many indirect and anecdotal suggestions of a serious population decline. For example, several ornithologists accustomed to finding the species at traditional birdwatching spots started to raise the alarm as an increasing number of these sites were being apparently abandoned (F. Johow and others, pers. comm.).

The naturally restricted range of the species and the presumed population decline led ornithologists in Chile to classify the species as Vulnerable more than a decade ago (Rottmann and López-Calleja 1992, CONAF 1993). More recently, BirdLife International (2000) included the Chilean Woodstar in the list of globally Endangered species. Although no specific threats are identified for the species, Stattersfield et al. (1998) underscore the cultivation of almost all the available habitat area as a major conservation issue in the desert valleys of northern Chile and southern Peru.

Old reports suggest that the species was, at least locally, very abundant, visiting gardens and agricultural fields in the valleys close to the city of Arica $\left(18^{\circ} 29^{\prime} \mathrm{S}, 70^{\circ} 19^{\prime} \mathrm{W}\right.$; Johnson and Goodall 1965). These authors reported that the species was the most abundant hummingbird in the Azapa valley, and that they once counted "over a hundred hovering like a swarm of bees all 
around a large flowering tree" ${ }^{\prime \prime}$ The southernmost record for this species is that of an apparently vagrant bird collected at Cobija $\left(22^{\circ} 36^{\prime} \mathrm{S}, 70^{\circ} 17^{\prime} \mathrm{W}\right)$, near the coast of Antofagasta (Johnson and Goodall 1965). Although the species has been recorded in the Tacna area of southern Peru (Parker 1982, Clements and Shany 2001), there have not been any recent records (Jaramillo 2003) and the presence of a stable population of the Chilean Woodstar in this country needs to be confirmed.

Because of the lack of any hard data regarding the species, it is difficult to identify the cause of any decline in the Chilean Woodstar. However, there are three factors that have been proposed as potentially important for the species' current status:

Habitat loss and degradation (Birdlife International 200o): The valleys where the species had historically been recorded in Chile have suffered much habitat alteration, and, consequently, the natural habitat of the species has probably been lost in most of its range.

Pesticides (J. C. Johow, F. Johow, pers. comm.): The warm and stable climate in the agricultural valleys of the Arica province creates the conditions for the development of several crop pests, which, in turn, are the cause of important levels of pesticide use (Rázmilic 1982, Salazar and Araya 2001). Along with the use of pesticides by private farmers, the government has conducted for decades an eradication programme for the Mediterranean fruit fly Ceratitis capitata that, in the past, even included aerial spraying with insecticides (Olalquiaga and Lobos 1993).

The irruption of a potential competitor, the Peruvian Sheartail Thaumastura cora (F. Johow, pers. comm.): In 1971, the Peruvian Sheartail was first recorded in Chile in the Azapa valley (Lavercombe and Hill 1972). During the subsequent years only a handful individuals were observed in the Azapa and Lluta valleys (Howell and Webb 1995, Marín 2004), but in the last decade it has been reported to be very common in the Azapa valley, even outnumbering the Chilean Woodstar in some areas (J. Aguirre, pers. obs, F. Johow, J. C. Johow, pers. comm.).

In this paper we report the results of a project to examine the conservation status of the Chilean Woodstar. Specifically we (I) provide the first quantitative population assessment for the species, (2) report some ecological and behavioural information relevant to the conservation of the species and (3) describe the main lines of action included in the Recovery Plan that came out of the project.

\section{Methods}

Fieldwork comprised several visits (mostly by J. A.) during recent years to the valleys where the species had been recorded (Lluta, Azapa and Vitor; see Study area), along with two 1o-day field trips (September 2003 and April 2004) aimed at estimating the total population size.

\section{Study area}

Because one of our goals was to determine the present distribution of the species in Chile, we sampled an area broader than the presumed range (Lluta, Azapa and Vitor valleys), covering the four vegetated valleys of Arica province, together with the northernmost valley of Iquique province, both in the Tarapacá region (Figure 1). Although fed by rivers from the high Andes, these valleys, throughout most of their length, cross the Atacama Desert and are thus surrounded by an extensive area almost devoid of any biological activity (the mean annual rainfall at the city of Arica is $0.5 \mathrm{~mm}$; Santibáñez 1981).

Due to a long history of human habitation (Santoro 1995), the main land use is agriculture, with native vegetation represented by some scattered trees of a few species such as Geoffroea decorticans, Acacia macracantha, Schinus molle and Prosopis tamarugo, and some riparian 


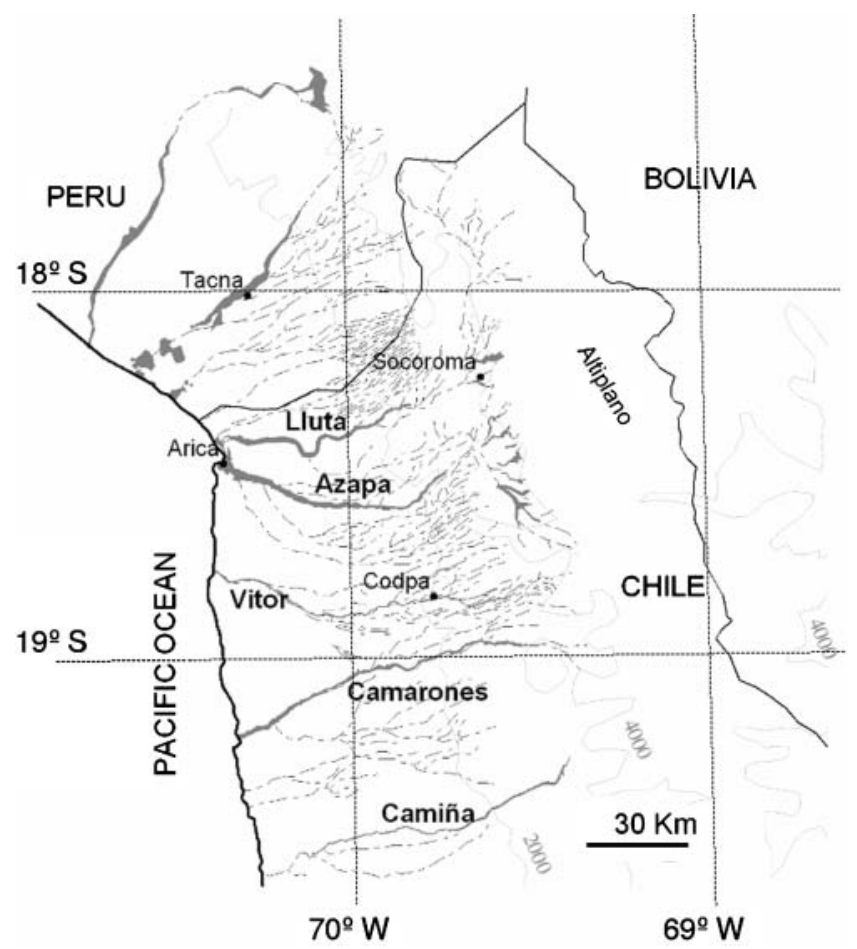

Figure 1 . The study area.

scrub. Lluta, Camarones and Camiña have severe salinity problems and, therefore, agriculture is restricted to some salt-resistant crops such as maize and alfalfa. Azapa and Vitor have lower salt concentrations allowing a more diverse agriculture, including crops such as tomatoes, pumpkins, garlic, maize and fruits such as guava, mango, citrus, and, most importantly, olives.

In four valleys, we sampled birds from sea level up to different altitudes ( $985 \mathrm{~m}$, Lluta; 1,425 $\mathrm{m}$, Azapa; 1,805 m, Vitor; 2,220 m, Camarones). In the Camiña valley, sampling stations ranged from 1,530 to $2,430 \mathrm{~m}$, because the lower part of the valley (called Tana creek) has a poor access and very little vegetation. We did not sample higher altitudes because almost all records of the woodstar had been made below 1,00o m (Johnson and Goodall 1965, del Hoyo et al. 1999). However, because we suspected that the species could engage in altitudinal migration (Fjeldsa and Krabbe 1990), we visited some sites up to 3,000 m. However, in these areas we did not conduct a formal sampling, but simply looked for the species in potentially suitable sites.

\section{Population estimates}

We estimated woodstar population size using fixed-radius point-counts (Bibby et al. 1992). We ruled out the use of mist-nets because our goal was to produce an estimate of the absolute densities over a very broad area, and because the species proved to be very difficult to catch during a preliminary mist-netting campaign (in August 2003).

At each point we recorded all birds seen or heard within and outside a $30 \mathrm{~m}$ radius during a 3 minute period. All woodstars seen flying within the inner area at the beginning of the counting time were assigned to that area. If they were recorded flying after some time, they were assumed to have come from outside and consequently were recorded as such. Records outside the $30 \mathrm{~m}$ radius were used to correct observations for the influence of detectability (Bibby et al. 1992). The 
short observation time and distance were chosen after a pilot study (August 2003), based on the visibility of the average habitat types and the behaviour of the species. All counts were done before 12 hoo.

We conducted point-counts in groups of six. The six counts at one 'sampling station' (a $200 \mathrm{~m}$ radius circle within which points were randomly placed) were conducted by a team of two people (three counts each). All six counts were done in a period of approximately 20 minutes. Because records coming from the six point-counts in one sampling station are clearly not independent, observations were averaged for the entire station. In each sampling station, we characterized the habitat in terms of types of land use (Table 1 ). The field crew comprised six people (including C. F. E., J. A., J. A. T., M. A. H. E. and M. A. V.).

In September 2003 we positioned a total of 199 sampling stations $(199 \times 6=1,194$ point counts) throughout the five valleys ( 36 in Lluta, 88 in Azapa, 28 in Vitor, 24 in Camarones and 23 in Camiña). During April 2004, two stations at the upper part of the Camarones valley could not be visited because the road had been destroyed by flooding.

During counting we experienced problems distinguishing some female woodstars from female sheartails due to their close resemblance (Jaramillo 2003). Although there seem to be some subtle field identification features such as a more pronounced tail movement in sheartails (Jaramillo 2003) and different vocalizations, birds seen from a distance could not be confidently identified. Therefore, we assigned unidentified females and juveniles to either species proportional to the relative abundance of males of each species in a particular area. Overall, the latter meant that $13.6 \%(n=11)$ of all recorded woodstars came from the reassignment of unidentified birds.

In order to calculate confidence intervals for the estimated populations, we analysed the data separately for each of the valleys. From preliminary observations we determined that the data, given our sampling protocol and the scarcity of the species, could not be normalized. Data from point-counts of rare species are known to have such problems and are thus better analysed using resampling techniques (Seavy et al. 2005). For that reason we used a Monte Carlo approach (Manly 1997) based on a spatially explicit simulation model. First, we digitized the limits of each valley from a satellite image considering a $50 \mathrm{~m}$ buffer area beyond the outermost pixels showing photosynthetic activity. Second, we located the sampling stations on the virtual valley in the exact same location they had in the real sampling. Third, we simulated a series of scenarios in which we varied the number of 'virtual woodstars' that the program randomly allocated in the valley. Fourth, we simulated a sample in the same fashion as was done in real life (i.e. six sampling plots within each $200 \mathrm{~m}$ radius station). For simulation purposes, and based on the distribution of real observations, we assumed that birds were detected with certainty within the $30 \mathrm{~m}$ radius, with probability 0.2 between 31 and $70 \mathrm{~m}$, and that no birds were recorded beyond $70 \mathrm{~m}$. We simulated 10,000 replicates for each scenario (a given total population size, $n=50$, 100,150 ...). Finally, for each scenario we recorded the frequency of the simulations that produced the same result as the real sampling and we plotted these frequencies against the

Table 1. Land use (percentage cover) in the desert valleys of Northern Chile.

\begin{tabular}{lccccc}
\hline Land use & \multicolumn{5}{c}{ Valley } \\
\cline { 2 - 6 } & Lluta & Azapa & Vitor & Camarones & Camiña \\
\hline Bare soil & 20 & 36 & 59 & 30 & 57 \\
Scrub & 25 & 10 & 18 & 40 & 11 \\
Native trees & 4 & 3 & 6 & 6 & 3 \\
Gardens/parks & 1 & 5 & 2 & 1 & 2 \\
Constructions & 5 & 11 & 2 & 4 & 4 \\
Crops (e.g. maize) & 46 & 18 & 6 & 18 & 23 \\
Fruit groves (e.g. olives) & 0 & 17 & 7 & 0 & 0 \\
\hline
\end{tabular}


population number in each scenario to produce a probability distribution for the total population size (see example in Figure 2). Following this procedure confidence intervals were calculated by determining the points beyond which the lower and upper $\alpha / 2$ portions of the total frequency were located. The mean of the distribution was used as the estimate of the average total population size (Figure 2).

Because there was a clear association between the abundance of woodstars and tree cover (see Results) we performed the same simulation protocol but now changing the "virtual woodstar" allocation procedure using a tree-cover map as covariate.

In order to assess any population-level relationships with other similar species we also estimated population sizes for the two other hummingbird species inhabiting the study area: the Peruvian Sheartail, and the Oasis Hummingbird Rhodopis vesper, the most abundant and widespread hummingbird in northern Chile (Johnson and Goodall 1965). For both species we used the same field sampling procedure. However, for the Oasis Hummingbird we calculated the confidence intervals on log-transformed count data because the higher abundance of the species allowed that operation and, at the same time, rendered the simulation procedure too timeconsuming.

\section{Ecological relationships}

During all visits to the study area we recorded as much information as possible on variables potentially relevant to the conservation of the species. These included plants used by woodstars for feeding and their phenology, breeding (timing and habitat), interactions with other species and potential sources of threat. In addition to our own observations, we conducted several

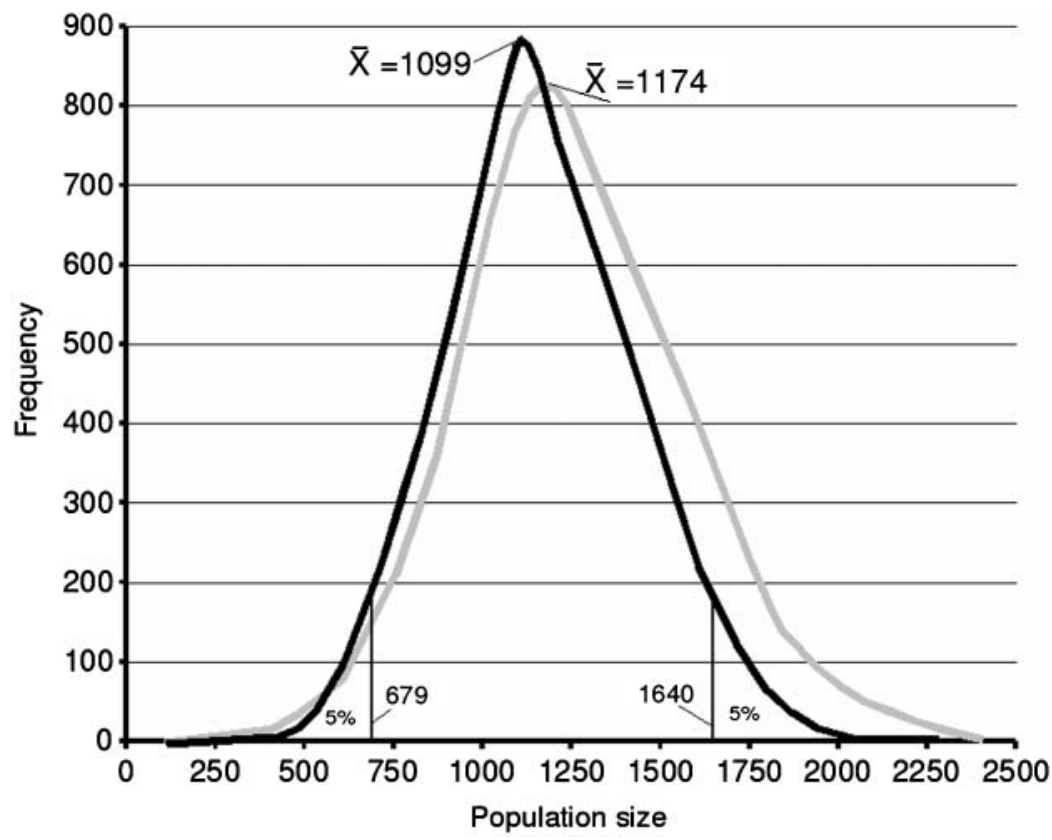

Figure 2. Frequency distribution of matches between simulated Chilean Woodstar sampling results and the real sampling for Azapa (September 2003) in relation to different population sizes. The grey line represents the results for a uniform random distribution of birds in the valley, while the black line represents the random distribution of birds but using tree cover as a covariate. For each population size, a total of 10,000 simulations were performed. 
interviews with local people, particularly farmers, and staff from wildlife-related government agencies.

From the sample data, we analysed the relationship between the abundance of woodstars and habitat attributes using generalized linear models and assuming a Poisson distribution (the dependent variable was the number of birds registered at each station). All statistical analyses were conducted using the R system (Ihaka and Gentleman 1996).

\section{Results}

\section{Distribution}

We recorded the species in only two of the five studied valleys: Azapa and Vitor. During September 2003, most woodstars were located at altitudes $<700 \mathrm{~m}$, with the exception of Codpa $(1,725-1,840 \mathrm{~m})$, in the upper Vitor valley, where we recorded a small population of the species. Additionally, we observed a bird that appeared to be a female woodstar in the Camiña valley at approximately $1,500 \mathrm{~m}$, although the bird was seen for a short period of time outside the sampling stations.

Our September visits to areas above 2,000 m produced no records of the species. In April 2004 we recorded a few woodstars visiting flowers of Calandrinia sp. at approximately 2,500 m between the Camarones river and the Vitor valley. Additionally, at the village of Socoroma $(3,000 \mathrm{~m})$, in the upper part of the Lluta valley, we recorded a female visiting a flowering eucalyptus tree. However, in the valleys of Azapa and Vitor the birds we found were distributed at the same altitudes as during the spring.

\section{Population estimates}

The simulations for all cases indicated that using tree cover as a covariate for the distribution of woodstars in the study area produced better results than distributing the birds in a uniform fashion. As an example, Figure 2 shows the frequency distributions for the two different models in Azapa, September 2003. Note that using tree cover produced a distribution with a higher maximum number of matches and a higher kurtosis. This pattern appeared in all studied cases and, consequently, we only used the models based on tree cover for calculations.

Table 2 shows the population estimates for the Azapa and Vitor valleys and the two studied seasons for the Chilean Woodstar along with the estimates for the Peruvian Sheartail and the Oasis Hummingbird. Numbers indicate that the main population of woodstars is found in the Azapa valley and that only $25-28 \%$ of the birds are found in the Vitor valley. During September 2003 the total population estimate for the Chilean Woodstar was 1,539 individuals (929-2,287;

Table 2. Population estimates for hummingbirds in the Azapa and Vitor valleys, northern Chile, in September 2003 and April 2004.

\begin{tabular}{llll}
\hline & Eulidia & Thaumastura & Rhodopis \\
\hline $\begin{array}{l}\text { Sept. 2003 } \\
\text { Azapa }\end{array}$ & $1,099(679-1,640)$ & $1,649(1,129-1,962)$ & $8,571(6,110-10,998)$ \\
Vitor & $440(250-647)$ & $-{ }^{a}$ & $1,504(966-2,037)$ \\
TOTAL & $1,539(929-2,287)$ & $1,649(1,129-1,962)$ & $10,075(7,076-13,035)$ \\
Apr. 2004 & & & \\
Azapa & $564(300-875)$ & $1,160(737-1,712)$ & $5,546(3,985-7,106)$ \\
Vitor & $194(99-298)$ & $-{ }^{a}$ & $796(386-1,205)$ \\
TOTAL & $758(399-1,173)$ & $1,160(737-1,712)$ & $6,342(4,371-8,311)$ \\
\hline
\end{tabular}

The $90 \%$ confidence interval for the population size is given in parentheses.

a At least one individual was seen in the Vitor valley, outside the sample. 
$90 \% \mathrm{CI}$ ), compared with 1,649 Sheartails and more than 10,000 individuals of Oasis Hummingbird. The last species has a much larger population size, because we sampled only a portion of its much greater geographical range (Jaramillo 2003).

The April survey showed an important reduction in the estimated population size of the three hummingbird species in the study area, although the Chilean Woodstar experienced the largest decrease, with a reduction of more than $50 \%$.

\section{Habitat associations}

When analysing the effects of habitat attributes on the species during September, the only variable that significantly affected the abundance of woodstars was tree cover (Azapa, $P=0.039$, $n=88$; Vitor, $P=0.028, n=28$ ), with more detections in areas with higher tree cover. In April no vegetation variables explained the abundance of the species.

\section{Feeding}

We observed woodstars feeding on the flowers of several plant species including native trees such as G. decorticans (chañar) and S. molle (pimiento), ornamentals such as Lantana camara, Pelargonium spp. and Bougainvillea sp., and several crop plants such as Medicago sativa (alfalfa), Allium spp. (garlic, onion) and Lycopersicon scullentum (tomato). Almost all the used species have entomophyllous flowers rather than typical ornithophyllous flowers. One of the most common hummingbird-pollinated plants in the area, the Chuve (Tecoma fulva), was only used by woodstars after the long red corollas had been ripped up by nectar robbers such as Conirostrum cinereum. An analysis of nestling droppings taken from old nests showed that their diet included several different arthropod taxa (mostly Hymenoptera, Homoptera and Coleoptera; M. A. H. E. and M. A. V., unpubl. data).

\section{Breeding}

The little information collected by us and other ornithologists indicates that most breeding activity of the species takes place twice a year. On occasions, active nests have been found in May and September. However, during April 2004 we recorded juveniles along with some partially constructed nests, suggesting that there exists some temporal variability. Most of the few nests $(n=8)$ we found were located in olive (Olea europaea) trees, at an average height of $2.3 \mathrm{~m} \pm$ 0.4 SD. A handful of other nests have been found in native shrubs and ornamental trees.

\section{Relationship with other hummingbirds}

Although we did not assess formally the level of competition between the Chilean Woodstar and the Peruvian Sheartail, we recorded some indirect evidence of such an interaction. For example, during August and September 2003 we observed a male woodstar defending its territory against the constant harassment of two male sheartails. In our visit in April 2004 to the site, the territory had been taken over by a male sheartail and no woodstars could be observed in the vicinity. Distribution data indicated that there may be some degree of spatial segregation between woodstars and sheartails and a positive association between woodstars and Oasis Hummingbirds. In Azapa, the best model (based on the AIC) to describe the September abundance of woodstars included tree cover $(P=0.003, n=88)$ and the abundance of Oasis Hummingbirds $(P=0.004, n=88)$ with a positive coefficient, and the abundance of Peruvian Sheartails $(P=0.057, n=88)$ with a negative coefficient. During April we found no relationships between the above variables. 
In Vitor we observed a significant positive association between Chilean Woodstars and Oasis Hummingbirds $(P=0.038, n=28)$.

\section{Sources of threat}

We detected significant levels of pesticide use, particularly in the Azapa valley. On a few occasions, we observed applications in the same area where hummingbirds were feeding and even nesting (in one Oasis Hummingbird nest). Although we have no direct evidence of mortality associated with pesticide use, we were shown two dead hummingbirds (female Chilean Woodstar and female Oasis Hummingbird) that were found in a plant nursery the day after a routine insecticide application. Finally, we observed that olive trees are frequently sprayed with water in order to reduce the attack by mould. This common practice is potentially harmful for nests that may be destroyed by the water.

\section{Discussion}

Our results suggest that the Chilean Woodstar faces a serious conservation problem. The existence of probably no more than 2,00o individuals within just two populations, and the partial evidence of a recent population decline support the classification of the species in the Endangered category (BirdLife International 2000). The records of supposedly vagrant individuals in southern Peru (Clements and Shany 2001), our observations of an individual in Camiña and sightings in areas above $2,000 \mathrm{~m}$, indicate that some woodstars do occur outside the two mentioned populations, but are not proof of the existence of other stable local populations.

The important reduction in the population estimates recorded by us during the April field season cannot be interpreted as a population crash but, more likely, as the result of the movement of a proportion of the population to zones outside the sampled valleys. Above 2,000 $\mathrm{m}$, rainfall is concentrated during the summer months (Rundel et al. 2003) causing most plant species to produce flowers between February and May, and woodstars and other hummingbirds to take advantage of that resource.

Because above 2,000 $\mathrm{m}$ there is a much higher density of smaller valleys (Figure 1 ), and some plant species even grow in between these valleys, during the summer and early autumn there is relative density of flowers that may create a sufficient level of connectivity for Woodstars to travel latitudinally. Figure 3 shows the hypothetical movement pathways that could be connecting the Azapa and Vitor populations and other areas where the species has been observed. The absence of such a corridor would imply that, for example, birds travelling from Azapa to Vitor would have to fly more than $30 \mathrm{~km}$ through the desert.

We confirmed some of the evidence pointing to a past population decline. First, after a thorough survey we did not find the species in the Lluta valley where it had been previously recorded, although in smaller numbers than in Azapa (Johnson and Goodall 1965). In fact, during our fieldwork we found only a handful of Oasis Hummingbirds and just one male sheartail, probably due to the scarcity of nectar-producing flowers in this valley. Rottmann (1972), in a short visit to Lluta in 1970, did not observe the species, and although this is not proof of its absence at that time, it suggests that the Chilean Woodstar population in that valley suffered a decline in the late 196os. Second, from being considered the most abundant hummingbird in Azapa half a century ago (Philippi et al. 1944, Barros 1954, Johnson and Goodall 1965), the Chilean Woodstar is currently the rarest species in this valley (Table 2).

There seems to be some degree of temporal coincidence between the last reports describing the species as abundant (Johnson and Goodall 1965) and the beginning of the massive use of pesticides in the Azapa valley. The Mediterranean fruit fly (Ceratitis capitata) was first detected in Chile in 1963, and by 1965 it had invaded most of the Tarapacá region (Olalquiaga and Lobos 1993). Since then, the Chilean government has implemented an eradication programme that has 


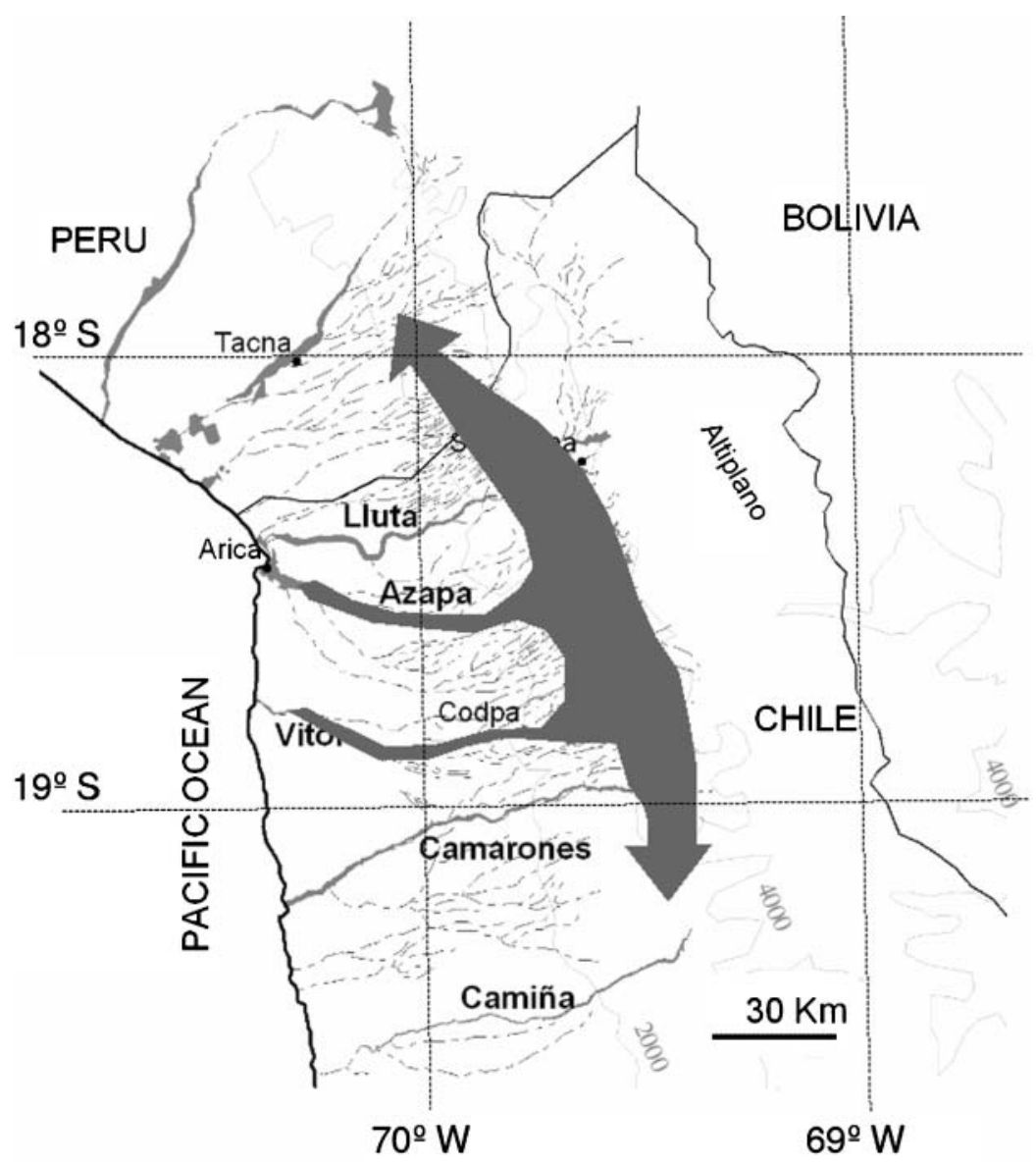

Figure 3. Hypothetical movement pathways for Chilean Woodstars throughout their known distributional range.

been successful in extirpating the species on several occasions, although re-infestations favoured by trade with neighbouring countries have forced a continuous control programme. McFarlane (1975) reported that during the 15 month period he spent in the Arica-Azapa area (April 1972 to July 1973) he encountered the species on only three occasions. We found the situation to be rather better, suggesting that the population may have partially recovered in that valley since the early 1970s. During the 1970s, the eradication programme in Arica-Azapa was reduced in intensity (Olalquiaga and Lobos 1993), which might have reduced the pressure on the species.

Most of the chemical control of the fruit fly has been based on Malathion, which is considered only slightly to moderately toxic to wild birds (Pascual 1994, George et al. 1995), and less frequently on systemic insecticides such as Dimethoate (Olalquiaga and Lobos 1993), which is very toxic and is known to contaminate the nectar of flowers (Barker et al. 1980). In Tacna and Moquehua, the Peruvian localities where the Chilean Woodstar has been recorded, there is a similar control programme for the fruit fly. In addition to the governmental pesticide applications, private growers rely on a heavy use of highly toxic chemicals to keep their crops pest-free (Salazar and Araya 2001).

The rapid increase in the population of the Peruvian Sheartail in Azapa during recent years seems to argue against an important role of pesticides as a limiting factor for hummingbirds 
during this period. Although a higher tolerance or a differential exposure level to pesticides by sheartails cannot be completely ruled out (see below), it does not seem reasonable that this factor alone could account for such a dramatic difference in population trend. Considering the morphological similarities and the relative spatial segregation between Chilean Woodstar and Peruvian Sheartail in the Azapa valley, it seems reasonable to hypothesize that the two species are potentially strong competitors. This situation, added to the apparently more aggressive behaviour of the sheartail (based on our anecdotal observations), suggests that the irruption of this species in the last two decades might have been a causal factor behind the decline of the woodstar. Many hummingbird species show interspecific territoriality (Cody 1968, Lyon et al. 1977) and the displacement of subordinate species by a dominant hummingbird is not infrequent (Pimm et al. 1985, Baltosser and Scott 1996). In Azapa, Peruvian Sheartails have occupied the lower parts of the valley where there are more residential areas, with an important supply of flowers throughout the year. Woodstars, on the other hand, are mostly located in the middle part of the valley where the dominant land use is agriculture. The latter could be inducing a higher exposure rate of woodstars to pesticides.

As in all hummingbird species, the existence of nectar-producing flowers is a key factor for the presence of the species. Probably due to their short beaks and small body size which enable them to exploit flowers with very small corollas, woodstars have clearly managed to incorporate in their diet a vast number of introduced plant species. However, the presence of some native species may still be a limiting factor for the species. For example, one of the reasons behind the disappearance of the species from the Lluta valley might be the cutting of almost all the "Chañares" (G. decorticans). This small tree is probably one of the most important food resources for the species due to its flower production, but, unfortunately, is very unpopular among farmers who consider it invasive and an attractant for mice.

Although information on the reproduction of the species is scant, the fact that most of the few nests observed by us were located in olive trees indicates that, similarly to the case of food, woodstars are relying mostly on exotic resources for breeding. The scarcity of native trees has probably pushed these birds to use orchards for nesting. Although olive trees do not receive as many pesticide applications as other fruit trees in the region, the use of high-pressure water spraying as a mould control technique can be potentially harmful for nests. However, the latter seems to be an easily manageable problem.

Because ours is the only population estimate for the species it is not possible to make any inference regarding a present trend, but the size and spatial structure of the remaining population, added to the persistence of important threat factors, suggest that the species is in a very delicate situation. In 1987 the Chilean Agricultural and Livestock Service (SAG) started the release of sterile male fruit flies as a complement to the use of pesticides (Olalquiaga and Lobos 1993) and since then they have been shifting towards the use of less toxic substances in the control of this pest. Moreover, while this manuscript was being written, the Mediterranean fruit fly was officially declared eradicated from the Tarapaca region, which will further reduce the amount of insecticides being used. However, the use of pesticides by private farmers shows no sign of decline.

Finally, if competition with the Peruvian Sheartail is, as we suspect, an important problem for the Chilean Woodstar, then the species' status is likely to worsen as sheartails are clearly increasing in numbers at a very rapid rate.

\section{Recovery plan}

In July 2004, at a meeting in the city of Arica, a Recovery Plan for the Chilean Woodstar was approved. This official document proposes a number of measures aimed at changing the species conservation status to, at least, the Vulnerable category by 2014. Specific goals are: to increase population size, to extend the present species' range to include southern Peru and other valleys of the Tarapacá region, and to involve the local population in the conservation of the species. 
Among the main activities listed in this Plan are:

1. A public awareness campaign. So far this campaign has included the publication of two brochures and a poster, and several talks have been given to different local people, particularly to school children. One of the goals of this campaign has been to help people identify the species and to encourage them to plant appropriate trees and shrubs. Most local people used to mistake the much commoner Oasis Hummingbird for the Chilean Woodstar. This situation misled some earlier local conservation efforts, such as the planting of Chuve Tecoma fulva which is an important resource for Oasis Hummingbirds but not for Chilean Woodstars. A recent promising sign of the involvement of the local community in the conservation of the species has been the designation in October 2004 of the Chilean Woodstar as the 'Official Bird' of the city of Arica.

2. A study of the competition between the Chilean Woodstar and the Peruvian Sheartail. This activity should include the experimental control of the latter species in some areas. It is also proposed to prevent the Vitor valley from being colonized by sheartails by actively relocating individuals.

3. The restoration of the natural vegetation in some small areas of the Azapa and Lluta valleys.

4. The incorporation of the conservation of the Chilean Woodstar as part of the agenda of the local Good Agricultural Practices committee.

5. The development of a permanent population monitoring programme.

6. The exploration of the convenience of an ex situ conservation project along with a programme for the reintroduction of the species in suitable areas within its historical range.

\section{Acknowledgements}

Funding for this study was provided by the Chilean Agricultural and Livestock Service (SAG). The authors thank Mónica Piña, Jorge Herreros, Barbara Knapton and Federico Johow for their help with part of the fieldwork. Johan Ingles kindly sent us a hard-to-get article. Comments by Huw Lloyd and an anonymous referee were very helpful in improving the manuscript.

\section{References}

Baltosser, W. H. and Scott, P. E. (1996) Costa's Hummingbird (Calypte costae). In A. Poole and F. Gill, eds. The birds of North America V. 251. Philadelphia, PA: The Academy of Natural Sciences.

Barker, R. J., Lehner, Y. and Kunzman, M. R. (1980) Pesticides and honey bees: nectar and pollen contamination in alfalfa treated with dimethoate. Arch. Environ. Con. Tox. 9: $125-133$.

Barros, O. (1954) Aves de Tarapacá. Investigaciones Zoológicas Chilenas 2: 35-64.

Bibby, C. J., Burgess, N. D. and Hill, D. A. (1992) Bird census techniques. London: Academic Press.

BirdLife International (2000) Threatened birds of the world. Barcelona and
Cambridge, U.K.: Lynx Edicions and BirdLife International.

Clements, J. F. and Shany, N. (2001) A field guide to the birds of Peru. California, USA: Ibis Publishing.

Cody, M. L. (1968) Interspecific territoriality among hummingbird species. Condor 70 : 270-271.

CONAF (1993) Libro rojo de los vertebrados terrestres de Chile. Santiago: Corporación Nacional Forestal (CONAF).

del Hoyo, J., Elliott, A. and Sargatal, J., eds. (1999) Handbook of the birds of the world. Volume 5. Barcelona: Lynx Edicions.

Fjeldsa, J. and Krabbe, N. (1990) Birds of the high Andes. Copenhagen, Denmark: Zoological Museum, University of Copenhagen. 
George, T. L., McEwen, L. C. and Petersen, B. E. (1995) Effects of grasshopper control programs on rangeland breeding bird populations. J. Range Manage. 48: 336-342.

Howell, S. and Webb, S. (1995) Noteworthy bird observation from Chile. Bull. Brit. Orn. Club 115: 57-66.

Ihaka, R. and Gentleman, R. (1996) R: a language for data analysis and graphics. J. Comp. Graph. Stat. 5: 299-314.

Jaramillo, A. (2003) Birds of Chile. New Jersey: Princeton University Press.

Johnson, A. W. and Goodall, J. D. (1965) The birds of Chile and adjacent regions of Argentina, Bolivia and Peru. Volume I. Buenos Aires: Platt Establecimientos Gráficos.

Lavercombe, B. J. and Hill, C. H. (1972) Aves observadas en la Provincia de Tarapacá incluyendo el hallazgo de dos especies y una subespecie nueva para Chile. Boletín Ornitológico (Chile) 4: 1-7.

Lyon, D. L., Crandall, J. and McKone, M. (1977) A test of the adaptiveness of interspecific territoriality in the Bluethroated Hummingbird. Auk 94: 448-454.

Manly, B. F. J. (1997) Randomization, bootstrap and Monte Carlo methods in biology. Second edition. London: Chapman and Hall/CRC.

Marín, M. (2004) Annotated checklist of the birds of Chile/Lista comentada de las aves de Chile. Barcelona: Lynx Edicions.

McFarlane, R. W. (1975) The status of certain birds in northern Chile. Bull. Int. Counc. Bird Preserv. 12: 300-309.

Olalquiaga, G. and Lobos, C. (1993) La mosca del Mediterráneo en Chile, introducción y erradicación. Santiago: Ministerio de Agricultura, Servicio Agrícola y Ganadero.

Parker, T. A. III (1982) First record of the Chilean Woodstar Eulidia yarrellii in Peru. Bull. Brit. Orn. Club 102: 86.

Pascual, J. A. (1994) No effects of a forest spraying of Malathion on breeding Blue Tits (Parus caeruleus). Environ. Toxicol. Chem. 13: 1127-1131.

Philippi, R. A., Johnson, A. W. and Goodall, J. D. (1944) Expedición ornitológica al norte de Chile. Boletín del Museo Nacional de Historia Natural (Chile) 22: 65-120 .
Pimm, S. L., Rosenzweig, M. L. and Mitchell, W. (1985) Competition and food selection: field tests of a theory. Ecology 66: 798-807.

Rázmilic, B. (1982) Presencia de pesticidas órgano clorados en aceitunas y aceite de oliva, Valle de Azapa, Chile. Idesia 6: 3-11.

Rottmann, J. (1972) Algunas aves silvestres de los valles agrícolas inferiores a $1.000 \mathrm{~m}$ de altitud en el Departamento de Arica. Idesia 2: 59-63.

Rottmann, J. and López-Calleja, M. V. (1992) Estrategia Nacional de Conservación de Aves. Santiago: Servicio Agrícola y Ganadero, División de Protección de los Recursos Naturales Renovables (Serie Técnica I).

Rundel, P. W., Gibson, A. C., Midgley, G. S., Wand, S. J. E., Palma, B., Kleier, C. and Lambrinos, J. (2003) Ecological and ecophysiological patterns in a pre-altiplano shrubland of the Andean Cordillera in northern Chile. Plant Ecol. 169: 179-193.

Salazar, E. R. and Araya, J. E. (2001) Respuesta de la Polilla del Tomate, Tuta absoluta (Meyrick), a insecticidas en Arica. Agricultura Técnica 61: 429-435.

Santibáñez, F. (1981) Zonificación de los recursos climáticos de la I región. Pp. 1-11 in F. Santibáñez, M. Etienne and $S$. Lailhacar, eds.. Delimitación y caracterización de los ecosistemas de la I región de Chile. Santiago, Chile: Sociedad Agrícola CORFO-SACOR.

Santoro, C. (1995) Late Prehistoric regional interaction and social change in a coastal valley of northern Chile. Ph.D. dissertation, University of Pittsburgh.

Seavy, N. E., Quader, S., Alexander, J. D. and Ralph, J. (2005) Generalized linear models and point count data: statistical considerations for the design and analysis of monitoring studies. Pp. 744-753 in C. J. Ralph and T. Rich, eds. Proceedings of the Third International Partners in Flight Conference. Asilomar, CA: USDA Forest Service, USDA (Gen. Tech. Rep. PSW-GTR-191).

Stattersfield, A. J., Crosby, M. J., Long, A. J. and Wege, D. C. (1998) Endemic Bird Areas of the world: priorities for biodiversity conservation. Cambridge, U.K.: BirdLife International (BirdLife Conservation Series no. 7). 
CRISTIÁN F. ESTADES*, MARTÍN A. H. ESCOBAR, JORGE A. TOMASEVIC, MARÍA ANGÉLICA VUKASOVIC

Laboratorio de Ecología de Vida Silvestre, Departamento de Manejo de Recursos Forestales, Universidad de Chile, Casilla 9206, Santiago, Chile, and Unión de Ornitólogos de Chile, Casilla 18183, Santiago, Chile

JUAN AGUIRRE

Unión de Ornitólogos de Chile, Casilla 18183, Santiago, Chile.

CHARIF TALA

Servicio Agrícola y Ganadero, Bulnes 140, Santiago, Chile.

*Author for correspondence; e-mail:cestades@uchile.cl

Received 4 May 2005; revision accepted 6 June 2006 